colleagues is beneficial a study will have to show that it reduces the mortality from cancer of the prostate. Such a screening programme will require a large population of patients and a minimum of 15 years' follow up.

D P S SANDHU C P CHILTON K W MUNSON

Derbyshire Royal Intirmary Derby DEl 2QY

1 Pedersen KV, Carlsson P, Varenhorst E, Lofman O, Berglund K. Screening for carcinuma of the prostate by digital rectal examination in a randomly selected population. Br Med $\mathcal{F}$ 1990;300:1041-4. (21 April.)

2 Love RR, Camilli AE. The value of screening. Cancer 1981;48 489-95.

3 Chodak GW. Early detection of prostate cancer. Horm Res 1989:32 (suppl 1):35-7

4 Thompson IM, Ernst JJ, Gangai MP, Spence CR. Adenocarcinoma of the prostate: results of routine urological screening. $\mathcal{F}$ Crol 1984;132:690-2.

5 Vihko $P$, Konturri $M$, Lukkarinen $O$, Ervasti J, Vihko $R$. Screening for carcinoma of the prostate. Cancer 1985;56:173-7. 6 Chodak GW, Schoenberg HW. Early detection of prostate cancer by routine screening. JAMA 1984;252:3261-4.

7 Lee F, Littrup PJ, Torp-Pedersen ST, et al. Prostate cancer comparison of transrectal ultrasound and digital rectal examination for screening. Radiology 1988;168:389-94.

Authors' REPLY,-We agree that there is no evidence from randomised studies that screening and potentially curative treatment reduce the overall mortality from carcinoma of the prostate and we agree that length and lead time biases must be considered in judging screening programmes. Contrary to other studies, our population of 1494 men was randomly selected from a total population of 9026 , so that the remaining 8432 who were not examined served as a control group. The follow up time, however, is still too short to enable any conclusions to be drawn.

Concerning the screening method and role of transrectal ultrasound screening, we found that the positive predictive value of digital rectal examination when performed by a urologist was 0.35 , which is similar to the best results of transrectal ultrasound scanning reported.

Staging lymphadenectomy was done in all patients who received potentially curative treatment (10 had radical prostatectomy and one had radiotherapy). One had minimal lymph node disease. Capsular invasion was found in seven cases after radical prostatectomy. These men received postoperative radiotherapy, although its value and the clinical significance of such invasion are not known.

In view of the final staging of the tumours it is most likely that we found and treated clinically significant carcinomas.

ERERHARD VARENHORST

Department of Urology

Norrköping, Sweden

KNUD V PEDERSEN

Department of Urology

University Hospital

Linköping, Sweden

SIR, - The recent paper by Dr Knud V Pedersen and colleagues described the assessment of cost and feasibility of screening for prostatic carcinoma, but their method of screening and their biopsy technique are baffling.

The authors do not say whether the cytologist who took biopsies of apparently abnormal prostates was aware of the clinical findings-this seems improbable because he took three fine needle aspirates from each lobe. If the cytologist was unaware of the site of the nodular areas several of the cancers might have been missed by not biopsying the nodular areas directly. This may explain the relatively low finding of a $30 \%(13 / 44)$ incidence of carcinoma when previous studies have shown an incidence of $50-75 \%$ of carcinoma in prostatic nodules. ${ }^{2}$ It is not stated which of the six biopsies taken in each patient were positive in the patients with carcinoma. Given these circumstances, I do not think that the technique is truly a screening test when such a potential for false negative results exists and the conclusions are thus flawed.

Random biopsying of the prostate gland under other circumstances is known to have a low yield. ${ }^{3}$ It is not surprising to find a $30 \%$ incidence of carcinoma in what is, after all, a highly selected group (men with nodular prostates on rectal examination). From necropsies and simple prostatectomy specimens figures of $5-40 \%$ have been suggested.

Finally, it is gratifying that there was a $100 \%$ response to the questionnaire sent to the men by the authors (though 331 did decline rectal examination for various reasons). This is unique in my experience and very impressive.

PETER A MCCARTHY

Department of Radiology, Hospital of the University of

Pennsylvania, Philadelphia, PA

1 Pedersen $\mathrm{K}$, Carlsson P, Varenhorst E, Löfman O, Berglund $\mathrm{K}$. Screening for carcinoma of the prostate by digital rectal examination in a randomly selected population. Br Med $\mathcal{J}$ 1990;300:1041-4. (21 April.)

2 Grayhack J, Bockrath J. Diagnosis of carcinoma of the prostate. Urology 1981;17(suppl):54

3 Catalona W. Yield from routine prostatic needle hiopsy in patients more than 50 years old referred for urologic evaluation: a preliminary report. $\mathcal{F}$ Urol $1980 ; 124: 844$

4 Catalona W, Scott W. Carcinoma of the Prostate. In: Walsh P. Gittes R, Perlmutter A, Stamey T, eds. Camphell's Urology. Philadelphia: W B Saunders, 1986:1463.

\section{Varicose veins}

SIR,-Mrs Linda de Cossart and Mr R S Kiff report anxiety concerning the safety of bilateral surgery for varicose veins and ask whether a policy of offering to operate on only one leg at a time is out of line with that of other surgeons.

I support that policy wholeheartedly and report that in my practice, owing to pressure on beds, I have not been able to perform bilateral varicose vein surgery for the past five years. Day patients have been offered unilateral flush saphenofemoral ligation and multiple avulsions under general anaesthesia with the option of having surgery for the other leg three months later. Patients are given a single dose of subcutaneous heparin 5000 units with premedication and on discharge are given elastic stockings to wear for three weeks. In our district there will always be another patient with a more pressing claim to an overnight stay in a surgical bed. A realistic appraisal of waiting time for routine surgery on varicose veins would have to be that it is infinite.

To date all my patients have accepted this policy without rancour. In over 300 cases over the past five years only one patient has had a pulmonary embolus. This patient was admitted to a private hospital, where he was given subcutaneous heparin 5000 units two hours preoperatively and twice a day for two days postoperatively and elastic stockings. Despite these measures the patient developed severe pleuritic chest pain after three weeks while on holiday abroad. On returning home he was admitted to hospital and given heparin, and a ventilation-perfusion scan confirmed the diagnosis of pulmonary embolus. The patient made a satisfactory recovery on anticoagulants.

A long term study is now needed to determine whether bilateral surgery is more dangerous than unilateral surgery, and another to show whether the addition of stripping the long saphenous vein from groin to knee, which sometimes precludes day case treatment, is of benefit.

P G BENTLEY

Kent and Sussex Hospital,

Tunbridge Wells,

Kent TN4 8AT

1 de Cossart L, Kiff RS. Varicose veins. Br Med J 1990;300:1273 (12 May.)

\section{Proliferative retinopathy with growth hormone deficiency and diabetes mellitus}

SIR,-Dr C H Thivolet and colleagues report an unusual case of proliferative retinopathy in a woman with growth hormone deficiency and insulin dependent diabetes mellitus.' Both hypertension and renal impairment are known to exacerbate pre-existing diabetic retinopathy but measurements of the patient's blood pressure and renal function are not described.

Insulin like growth factor $I$ is suggested to be a local mediator of diabetic retinopathy. But the authors do not take into account that only a small free fraction of the factor is present in the circulation and that most is bound to carrier proteins. When variations in glycaemic control, duration of diabetes, and renal function are controlled for the total concentrations of circulating insulin like growth factor I are relatively low in patients with advanced retinopathy. ${ }^{2}$ Local tissue concentrations of free insulin like growth factor I and its binding proteins are probably more relevant, and recently the $40 \mathrm{kDa}$ complex of the factor and small binding protein has been found in the vitreous of patients with proliferative diabetic retinopathy. ${ }^{3}$ Further studies are required to elucidate the role of insulin like growth factor I and its binding proteins in the development of diabetic retinopathy.

The authors also state that hyperinsulinism may explain the observed normal concentrations of insulin like growth factor $I$ in the patient and that insulin may be critical in the control of the secretion of the factor. Unfortunately, no measurements of insulin or $\mathrm{C}$ peptide secretion are detailed to support this contention. This explanation is probably oversimplified because evidence is growing of an inverse relation between concentrations of insulin and one of the small binding proteins known as insulin like growth factor binding protein $\mathrm{I}^{+}$Understanding of the effect insulin like growth factor I and its binding proteins have on glucose homeostasis is still incomplete.

J D QUIN

A C MACCUISH

Diabetic Unit,

Glasgow Royal Infirmary,

Glasgow G4 0SF

Gartnavel General Hospital,

Glasgow G12 0YN

1 Thivolet $\mathrm{CH}$, Mirakian P, Chatelain P, Fournier P, Tournaire J. Proliferative retinopathy in a woman with growth hormon deficiency and diabetes mellitus. Br Med $\mathcal{Y}$ 1990;300:979-80. (14 April.)

2 Arner P, Sjorberg S, Gjottersbeg M, Skottner A. Circulating insulin like growth factor $I$ in type I (insulin-dependent) diabetic patients with retinopathy. Diabetologia 1989;32 753-8

3 Grant M, Russell B, Fitzgerald C, Merimee TJ. Insulin like growth factors in vitreous: studies in control and diabetic
subjects with neovascularization. Diabetes 1986;35:416-20.

4 Holly JMP, Biddlecombe RA, Dunger DB, et al. Circadian variation of growth hormone independent insulin like growth factor binding protein in diabetes mellitus and its relationship to insulin. A new role for insulin? Clin Endocrinol ship to insulin.

AUTHOR'S REPLY,-The suggested relation between blood pressure and renal impairment and proliferative retinopathy in our patient was unlikely to be important because proteinuria and hypertension occurred later.

Total concentrations of circulating insulin like growth factor $I$ in proliferative retinopathy may be either increased or normal in adult patients. The study by Arner et al, showing low insulin like growth factor I concentrations, is unique and should be reproduced by others. We agree that the complex of $40 \mathrm{kd}$ and insulin like growth factor I may be particularly important and we will measure 